\title{
Analisis Pengaruh Pengetahuan Perpajakan, Pelayanan Fiskus Dan Sanksi Denda Terhadap Kepatuhan Wajib Pajak Dalam Membayar Pajak Bumi Dan Bangunan Perdesaan Dan Perkotaan Di Kota Pasuruan
}

\author{
(Analysis Effect Of Taxation Knowledge, Government Services And Sanctions Fines \\ Against Compliance Taxpayers In Paying Property Tax \\ Rural And Urban In Pasuruan City)
}

\author{
Fita Fitrianingsih*, Sudarno, Taufik Kurrohman \\ Jurusan Akuntansi, Fakultas Ekonomi dan Bisnis, Universitas Jember (UNEJ) \\ Jln. Kalimantan 37, Jember 68121 \\ E-mail: fita.fitrianingsih@gmail.com
}

\begin{abstract}
Abstrak
Penelitian ini bertujuan untuk menguji pengaruh dari pengetahuan perpajakan, pelayanan fiskus, dan sanksi denda terhadap kepatuhan wajib pajak dalam membayar pajak bumi dan bangunan perdesaan dan perkotaan di Kota Pasuruan. Penelitian ini menggunakan data primer yang diperoleh dari data kuesioner yang dibagikan kepada para responden wajib pajak bumi dan bangunan yang menjadi sampel. Metode analisis data adalah analisis regresi linier berganda dengan menggunakan SPSS versi 23. Hasil penelitian menunjukkan bahwa pengetahuan perpajakan secara parsial tidak berpengaruh terhadap kepatuhan wajib pajak, sedangkan pelayanan fiskus dan sanksi denda secara parsial berpengaruh positif terhadap kepatuhan wajib pajak dalam membayar pajak bumi dan bangunan perdesaan dan perkotaan. Pengetahuan perpajakan, pelayanan fiskus dan sanksi denda secara simultan atau bersama - sama berpengaruh positif terhadap kepatuhan wajib pajak.
\end{abstract}

Kata Kunci: kepatuhan wajib pajak, pengetahuan perpajakan, pelayanan fiskus, sanksi denda

\begin{abstract}
This study aimed to examine the effect of taxation knowledge, government services, and sanctions fines against compliance taxpayers in paying property tax rural and urban in pasuruan city. This study uses primary data obtained from the questionnaires data distributed to respondents property taxpayer into the sample. Method of data analysis is multiple linear regression with program data processing uses SPSS version 23. The results showed that the taxation knowledge partially no effect on compliance taxpyers, while government service and sanctions fines partially positive effect on compliance taxpayer in paying property tax in rural and urban. Taxation knowledge, government services and sanctions fines simultaneously or together positive effect on compliance taxpayers.
\end{abstract}

Keywords: compliance taxpayers, taxation knowledge, government services, and sanctions fines

\section{Pendahuluan}

Pajak Bumi dan bangunan yang memiliki dampak yang luas bagi daerah, dikarenakan sepenuhnya digunakan untuk pembangunan di daerah yang bersangkutan yang sesuai dengan UU No. 28 tahun 2009 tentang penerimaan Pajak Bumi dan Bangunan, sehingga perlu bagi pemerintah untuk meningkatkan pencapaian target penerimaan Pajak Bumi dan Bangunan sebagai sumber Pendapatan Asli Daerah (PAD) (Budhiarta dan Jati ; 2016). Ekstenstifikasi maupun Intensifikasi merupakan contoh untuk meningkatkan pencapaian target penerimaan pajak yang dilakukan oleh pemerintah. Selain usaha tersebut, terdapat beberapa faktor lain yang dapat dilakukan, dimana menurut Ernawati (2013) usaha dalam mengoptimalkan penerimaan pajak itu sendiri adalah dengan meningkatkan faktor - faktor yang ada di dalam diri wajib pajak itu sendiri, untuk hal ini dapat ditempuh dengan meningkatkan kepatuhan wajib pajak.

Kepatuhan wajib pajak menurut Keputusan Menteri Keuangan No.544/ KMK.04/ 2000 (dalam Hudany, 2015) adalah tindakan wajib pajak dalam pemenuhan kewajiban perpajakannya sesuai dengan ketentuan peraturan perundang undangan dan peraturan pelaksanaan perpajakan yang berlaku dalam suatu Negara. Kepatuhan wajib pajak dalam membayar Pajak Bumi dan Banngunan Perdesaan dan Perkotaan dapat dikaitkan dengan melihat perilaku wajib pajak dalam membayar pajak tepat waktunya, melaporkan setiap bentuk perubahan dari tanah/rumah yang ditempati sendiri ataupun tanah/rumah yang ditempati tetangga kepada petugas pajak, mencari informasi terkait dengan terbitnya SPPT PBB baik milik sendiri maupun milik tetangga kepada petugas pajak.

Kota Pasuruan pada tahun 2013 menurut Mappi Jatim pernah memiliki persentase realisasi yang masih di bawah $100 \%$ pada batas waktu pembayaran Pajak Bumi dan Bangunan. Selain itu pada beberapa tahun terakhir persentase realisasi penerimaan PBB Kota Pasuruan mengalami fluktuatif yang cenderung menurun dari tahun 2014, hal tersebut dapat tejadi karena kepatuhan wajib pajak dalam membayar pajaknya masih rendah dan cenderung menurun dari tahun 2013, yang dapat dilihat pada tabel berikut ini :

* Corresponding Author 
Tabel 1. Tingkat Kepatuhan Wajib Pajak PBB di Kota Pasuruan

\begin{tabular}{cccc}
\hline Tahun & Jumlah WP & Sudah Bayar & Persentase \\
\hline 2012 & 59.656 & 39.559 & $66.31 \%$ \\
2013 & 60.349 & 44.180 & $73.20 \%$ \\
2014 & 61.446 & 44.234 & $71.98 \%$ \\
2015 & 62.618 & 43.901 & $70.10 \%$ \\
2016 & 63.445 & 43.956 & $69.28 \%$ \\
\hline
\end{tabular}

Sumber : Bapeda Kota Pasuruan, data diolah, 2017.

Kita dapat menyimpulkan dari hal tersebut bahwa Kota Pasuruan terkait tingkat kepatuhan wajib pajaknya yaitu masih rendah, sehingga perlu untuk dilakukan penelitian. Diketahui bahwa faktor - faktor yang mempengaruhi kepatuhan bermacam - macam, namun dalam penelitian ini peneliti memilih ketiga variabel yaitu Pengetahuan Perpajakan, Pelayanan Fiskus, dan Sanksi Denda dengan alasan karena pada penelitian sebelumnya ketiga variabel tersebut memiliki hasil penelitian yang berbeda. Oleh karena itu berdasarkan pemaparan latar belakang diatas, maka rumusan masalah dari penelitian ini adalah apakah pengetahuan perpajakan, pelayanan fiskus, dan sanksi denda berpengaruh terhadap kepatuhan wajib pajak, sedangkan tujuan dari penelitian ini adalah :

1. Untuk menguji pengaruh pengetahuan perpajakan terhadap kepatuhan wajib pajak

2. Untuk menguji pengaruh pelayanan fiskus terhadap kepatuhan wajib pajak

3. Untuk menguji pengaruh sanksi denda terhadap kepatuhan wajib pajak.

\section{Metode}

\section{Jenis dan Sumber Data}

Jenis data dalam penelitian ini adalah Data Primer dan Data Sekunder. Data primer dalam penelitian ini di peroleh dari kuesioner yang disebarkan kepada responden, sedangkan data sekunder penelitian ini di dapatkan dari Pemerintah Daerah Kota Pasuruan di Badan Pendapatan Daerah Kota Pasuruan yang terdiri dari:

a. Jumlah Wajib Pajak Bumi dan Bangunan Perdesaan dan Perkotaan yang terdaftar dari Tahun 2012- 2016 di Bappeda Kota Pasuruan

b. Jumlah ketepatan membayar Pajak Bumi dan Bangunn Perdesaan dan Perkotaan yang terdaftar dari Tahun 20122016 di Bappeda Kota Pasuruan

c. Target dan Realisasi penerimaan Pajak Bumi dan Bangunan Perdesaan dan Perkotaan Kota Pasuruan dari Tahun 2012 -2016.

\section{Populasi dan Sampel}

Populasi dalam penelitian ini adalah seluruh wajib pajak bumi dan bangunan perdesaan dan perkotaan di Kota Pasuruan yang terdaftar tahun 2016. Teknik pengambilan sampel pada peneltian ini menggunakan metode probability sampling dengan teknik random sampling cluster. Penentuan ukuran sampel pada penelitian ini adalah dengan menggunakan rumus Sarwono (2011:89) sebagai berikut :

$$
n=\frac{N}{1+N(e)^{2}}
$$

Keterangan :

$\mathrm{n}=$ ukuran sampel

$\mathrm{N}=$ Populasi

$\mathrm{e}=$ tingkat presisi(ditentukan $10 \%)$

Setelah mengetahui jumlah populasi dan melakukan perhitungan ukuran sampel, maka diperoleh jumlah sampel sebanyak 100 wajib pajak bumi dan bangunan. Dari jumlah tersebut kemudian dilakukan perhitungan secara proporsioal untuk menentukan jumlah sampel per kecamatan dengan hasil sebagai berikut :

Tabel 2. Penentuan Sampel Per Kecamatan

\begin{tabular}{cccc}
\hline Kecamatan & Populasi & Proposional & $\begin{array}{c}\text { Jumlah } \\
\text { sampel }\end{array}$ \\
\hline Gadingrejo & 15145 & $\begin{array}{c}(15145: 63445) \\
\text { x } 100 \%\end{array}$ & 24 \\
Purworejo & 19968 & $\begin{array}{c}(19968: 63445) \\
\times 100 \%\end{array}$ & 32 \\
Bugul Kidul & 11501 & $\begin{array}{c}(11501: 63445) \\
\times 100 \%\end{array}$ & 18 \\
Panggungrejo & 16831 & $\begin{array}{c}(16831: 63445) \\
\times 100 \%\end{array}$ & 26 \\
\hline Jumlah & 63445 & & 100
\end{tabular}

Sumber : Bapeda Kota Pasuruan, data diolah, 2017.

\section{Metode Analisis Data}

Metode analisis data dan pengujian hipotesis dalam penelitian ini meliputi statistik deskripstif, uji kualitas data yang terdiri dari uji validitas dan reabilitas, uji asumsi klasik yang terdiri dari uji normalitas, uji heteroskedastisitas, dan uji multikolinearitas, kemudian analisis regresi linier berganda, koefisien determinasi, uji $\mathrm{F}$, dan uji t dengan menggunakan program SPSS versi 23.

\section{Hasil dan Pembahasan}

\section{Hasil}

\section{Statistik Deskriptif}

Menurut Sudarmanto (2013) statistik deskriptif berguna untuk memberikan gambaran atau pengorganisasian suatu objek yang diambil melalui data sampel atau populasi , tanpa melakukan analisis dan membuat kesimpulan yang berlaku umum. Berikut adalah hasil dari statistik deskriptif :

Tabel 3. Statistik Deskriptif

\begin{tabular}{|c|c|c|c|c|c|}
\hline Keterangan & $\mathrm{N}$ & Min & $\operatorname{Max}$ & Mean & $\begin{array}{c}\text { Std. } \\
\text { Deviation }\end{array}$ \\
\hline $\begin{array}{l}\text { Pengetahuan } \\
\text { Perpajakan }\end{array}$ & 100 & 2,25 & 4.00 & 3.36 & 0.35 \\
\hline $\begin{array}{l}\text { Pelayanan } \\
\text { Fiskus }\end{array}$ & 100 & 1,80 & 4.00 & 3.25 & 0.38 \\
\hline Sanksi Denda & 100 & 1,00 & 4.00 & 3.03 & 0.70 \\
\hline Kepatuhan & 100 & 2,00 & 4.00 & 3.07 & 0.40 \\
\hline $\begin{array}{ll}\text { Valid } & N \\
\text { (listwise) } & \end{array}$ & 100 & & & & \\
\hline
\end{tabular}

Sumber : data primer, diolah, 2017. 
Berdasarkan tabel 3, maka dapat diketahui bahwa untuk variabel pengetahuan perpajakan mempunyai nilai rata - rata sebesar 3.365, nilai minimumnya sebesar 2.25 , dan nilai maksimumnya sebesar 4.00 dengan standar deviasi 0.35784 . Variabel pelayanan fikus mempunyai nilai rata - rata sebesar 3.250 , nilai minimumnya sebesar 2.25 , dan nilai maksimum sebesar 4.00 dengan standar deviasi 0.38599. Variabel sanksi denda mempunyai nilai rata - rata sebesar 3.035, nilai minimumnya sebesar 1.00 , dan nilai maksimum sebesar 4.00 dengan standar deviasi 0.70084. Variabel kepatuhan mempunyai nilai rata - rata sebesar 3.072, nilai minimumnya sebesar 2.00, nilai maksimum sebesar 4.00 dengan standar deviasi 0.40253 .

\section{Uji Kualitas Data}

\section{Uji Validitas}

Uji Validitas digunakan untuk mengetahui apakah alat ukur yang telah dibuat dapat digunakan untuk mengukur suatu hal secara tepat (Sudarmanto, 2013 : 56). Untuk mengetahui apakah alat ukur penelitian ini valid atau tidak menggunakan aturan dari korelasi product moment dari Pearson. Hasil pengujian dapat dilihat pada tabel berikut ini:

Tabel 4. Uji Validitas Kuesioner

\begin{tabular}{|c|c|c|c|c|}
\hline Variabel & $\begin{array}{l}\text { Butir } \\
\text { Soal }\end{array}$ & $\begin{array}{l}\text { Nilai } r \\
\text { hitung }\end{array}$ & $\begin{array}{c}\text { Nilai r } \\
\text { tabel }\end{array}$ & Keterangan \\
\hline \multirow{4}{*}{$\begin{array}{l}\text { Pengetahuan } \\
\text { Perpajakan }\end{array}$} & 1 & 0,589 & 0,165 & Valid \\
\hline & 2 & 0,731 & 0,165 & Valid \\
\hline & 3 & 0,688 & 0,165 & Valid \\
\hline & 4 & 0,596 & 0,165 & Valid \\
\hline \multirow{5}{*}{$\begin{array}{l}\text { Pelayanan } \\
\text { Fiskus }\end{array}$} & 1 & 0,548 & 0,165 & Valid \\
\hline & 2 & 0,701 & 0,165 & Valid \\
\hline & 3 & 0,656 & 0,165 & Valid \\
\hline & 4 & 0,623 & 0,165 & Valid \\
\hline & 5 & 0,593 & 0,165 & Valid \\
\hline \multirow{4}{*}{$\begin{array}{l}\text { Sanksi } \\
\text { Denda }\end{array}$} & 1 & 0,778 & 0,165 & Valid \\
\hline & 2 & 0,818 & 0,165 & Valid \\
\hline & 3 & 0,882 & 0,165 & Valid \\
\hline & 4 & 0,794 & 0,165 & Valid \\
\hline \multirow{5}{*}{$\begin{array}{l}\text { Kepatuhan } \\
\text { Wajib Pajak }\end{array}$} & 1 & 0,358 & 0,165 & Valid \\
\hline & 2 & 0,692 & 0,165 & Valid \\
\hline & 3 & 0,700 & 0,165 & Valid \\
\hline & 4 & 0,614 & 0,165 & Valid \\
\hline & 5 & 0,652 & 0,165 & Valid \\
\hline
\end{tabular}

Sumber : Data Primer, diolah, 2017.

Diketahui apabila $\mathrm{r}$ hitung $>\mathrm{r}$ tabel, maka dapat dinyatakan bahwa alat ukur tersebut valid. Berdasarkan tabel 4 diperoleh hasil bahwa $\mathrm{r}$ hitung $>\mathrm{r}$ tabel, sehingga dapat disimpulkan bahwa alat ukur atau kuesioner dalam penelitian ini sudah tepat atau valid.

\section{Uji Reliabilitas}

Uji reliabilitas merupakan uji yang digunakan untuk mengetahui apakah alat ukur penelitian sudah stabil atau konsisten sehingga dapat memberikan hasil pengukuran yang tidak berubah - ubah (Sudarmanto, 2013 : 81). Untuk mengetahui hal tersebut, penelitian ini menggunakan metode belah dua dari Guttman. Hasil pengujian dapat dilihat pada tabel berikut ini :

Tabel 5. Uji Reliabiltas Kuesioner

\begin{tabular}{cccc}
\hline $\begin{array}{c}\text { Koef. } \\
\text { Guttman }\end{array}$ & $\begin{array}{c}\text { Koef. } r \\
\text { tabel }\end{array}$ & Kondisi & Keterangan \\
\hline 0,536 & 0,165 & $r_{\text {hitung }}>$ & Reliabel \\
& & $r_{\text {tabel }}$ & \\
\hline
\end{tabular}

Sumber : data primer, diolah, 2017.

Diketahui apabila $\mathrm{r}$ hitung $>\mathrm{r}$ tabel, maka dapat dinyatakan bahwa alat ukur tersebut reliabel. Berdasarkan tabel 4.8 diperoleh hasil bahwa $\mathrm{r}$ hitung $>\mathrm{r}$ tabel, sehingga dapat disimpulkan bahwa alat ukur atau kuesioner dalam penelitian ini reliabel.

\section{Uji Asumsi Klasik \\ Uji Normalitas}

Uji normalitas digunakan untuk mengetahui apakah dalam model regresi kedua variabel yang ada yaitu variabel bebas dan terikat mempunyai distribusi data yang normal atau mendekati normal. Hasilnya dapat dilihat pada gambar berikut :

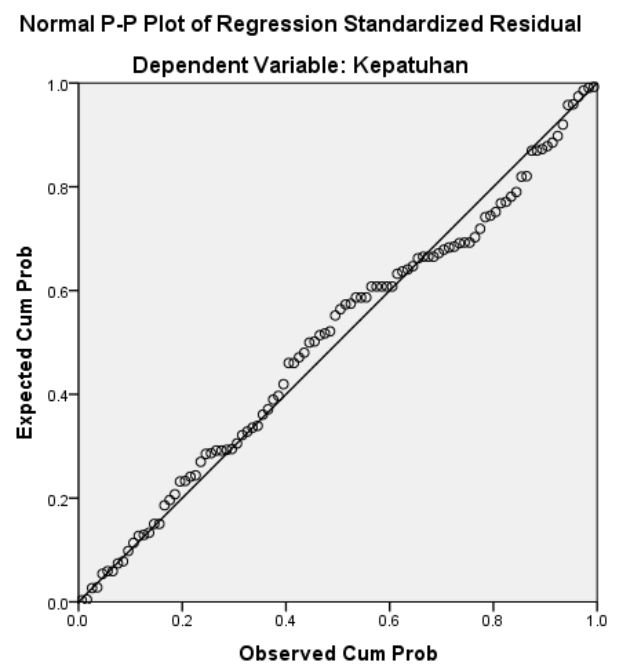

Gambar 1. Uji Normalitas

Berdasarkan hal tersebut maka dapat disimpulkan bahwa data pada penelitian ini terdistribusi normal, karena gambar 1 menunjukkan bahwa titik - titik data menyebar di sekitar garis diagonal dan mengikuti arah garis diagonal.

\section{Uji Heteroskedastisitas}

Uji heteroskedastisitas ini bertujuan untuk menguji model regresi terjadi sama atau ketidaksamaan variance dari 
residual satu pengamatan ke pengamatan lain. Hasilnya dapat dilihat pada tabel berikut :

Tabel 6. Uji Heteroskedastisitas

\begin{tabular}{ccc}
\hline Koef $r_{\text {hitung }}$ & Koef $r_{\text {tabel }}$ & Kondisi \\
\hline 0,039 & 0,165 & $r_{\text {hitung }}<r_{\text {tabel }}$ \\
$-0,062$ & 0,165 & $r_{\text {hitung }}<r_{\text {tabel }}$ \\
$-0,260$ & 0,165 & $r_{\text {hitung }}<r_{\text {tabel }}$
\end{tabular}

Sumber : data primer, diolah, 2017.

Berdasarkan hasil tersebut dapat disimpulkan bahwa data bebas dari gejala heteroskedastisitas, karena pada tabel 4 menunjukkan bahwa kondisi data memiliki $\mathrm{r}$ hitung $<\mathrm{r}$ tabel.

\section{Uji Multikolinearitas}

Uji multikolinearitas bertujuan untuk menguji apakah pada sebuah model regresi ditemukan adanya korelasi antar variabel independen. Hasilnya dapat dilihat pada tabel berikut :

Tabel 7. Uji Multikolinearitas

\begin{tabular}{lcc}
\hline \multicolumn{1}{c}{ Variabel } & VIF & Keterangan \\
\hline $\begin{array}{l}\text { Pengetahuan } \\
\text { Perpajakan }\end{array}$ & 1.233 & VIF $<10$ \\
Pelayanan Fiskus & 1.230 & $\begin{array}{c}\text { Tidak terjadi gejala } \\
\text { multikolinearitas }\end{array}$ \\
Sanksi Denda & 1.067 & \\
\hline
\end{tabular}

Sumber : data primer, diolah, 2017.

Berdasarkan hasil tersebut maka dapat disimpulkan bahwa data bebas dari gejala multikolinearitas, karena pada tabel 5 menunjukkan bahwa nilai VIF masing - masing variabel kurang dari 10.

\section{Analisis Regresi Linier Berganda}

Analisis uji regresi linier berganda adalah analisis yang digunakan untuk mengetahui besarnya pengaruh dari variabel independen terhadap variabel dependen. Hasil dari analisis regresi linier berganda dapat dilihat dalam tabel berikut ini.

Tabel 8. Analisis Regresi Linier Berganda

\begin{tabular}{ccc}
\hline Variabel & Koef.Regresi & Sig. \\
\hline Konstanta & 1,304 & 0,002 \\
Pengetahuan Perpajakan & 0,152 & 0,187 \\
Pelayanan Fiskus & 0,281 & 0,009 \\
Sanksi Denda & 0,113 & 0,041 \\
\hline
\end{tabular}

Sumber : data primer, diolah, 2017.

Berdasarkan hasil tersebut dapat diperoleh model persamaan regresi linier berganda sebagai berikut :

$$
\mathrm{Y}=1,304+0,152 X_{1}+0,281 X_{2}+0,113 X_{3}+\mathrm{e}
$$

Koefisien Determinasi $\left(\mathrm{R}^{2}\right)$
Tabel 9. Koefisien Determinasi

\begin{tabular}{ccccc}
\hline Model & $\mathrm{R}$ & $\begin{array}{c}R \\
\text { Square }\end{array}$ & $\begin{array}{c}\text { Adjusted } \\
R\end{array}$ & $\begin{array}{c}\text { Std. Erorr } \\
\text { of the } \\
\text { Square }\end{array}$ \\
\hline 1 & $0.43^{9^{a}}$ & 0.193 & 0.168 & 0.36720
\end{tabular}

Sumber : data primer, diolah, 2017.

Berdasarkan hasil analisis pada tabel 9 diperoleh hasil koefisien determinasi ( $\mathrm{R}$ square) sebesar 0,168, hal ini berarti 16,8\% perubahan Kepatuhan Wajib Pajak dipengaruhi oleh Pengetahuan Perpajakan, Pelayanan Fiskus, dan Sanksi Denda, sedangkan sisanya sebesar $83,2 \%$ disebabkan oleh faktor lain yang tidak masuk dalam model persamaan regresi yang dibuat.

\section{Uji F}

Uji F merupakan analisis yang digunakan untuk mengetahui kelayakan model regresi linier berganda sebagai alat analisis yang menguji pengaruh variabel independen terhadap variabel dependen. Hasil dari uji $\mathrm{F}$ dapat dilihat dari tabel berikut :

Tabel 10. Uji F

\begin{tabular}{cccccc}
\hline $\begin{array}{c}\text { Mode } \\
1\end{array}$ & $\begin{array}{c}\text { Sum of } \\
\text { Squares }\end{array}$ & df & $\begin{array}{c}\text { Mean } \\
\text { Square }\end{array}$ & F & Sig. \\
\hline 1 & 3.098 & 3 & 1.033 & 7.658 & $0.00^{0^{b}}$
\end{tabular}

Sumber : data primer, diolah, 2017.

Berdasarkan hasil analisis yang diperoleh nilai $\mathrm{F}$ hitung sebesar 7,658 dengan tingkat signifikansi sebesar 0,000 lebih kecil daripada 0,05, maka dapat disimpulkan bahwa model regresi dapat digunakan untuk memprediksi pengaruh pengetahuan perpajakan, pelayanan fiskus dan sanksi denda terhadap kepatuhan wajib pajak.

Uji t

Uji t merupakan uji hipotesis yang digunakan untuk menguji bagaimana pengaruh masing - masing dari variabel bebas terhadap variabel terikat. Berdasarkan hasil pengujian, nilai $\mathrm{t}$ hitung dari masing - masing variabel adalah sebagai berikut :

Tabel 11. Uji t

\begin{tabular}{lcc}
\hline \multicolumn{1}{c}{ Variabel } & $t_{\text {hitung }}$ & $t_{\text {tabel }}$ \\
\hline Pengetahuan Perpajakan & 1,330 & 1,660 \\
Pelayanan Fiskus & 2,652 & 1,660 \\
Sanksi Denda & 2,070 & 1,660 \\
\hline
\end{tabular}

Sumber : data primer, diolah, 2017.

Berdasarkan tabel 8 diketahui bahwa :

a. Pengetahuan perpajakan $\left(X_{1}\right)$ memiliki nilai t hitung lebih kecil dari $\mathrm{t}$ tabel yaitu $1,330<1,660$, maka $\mathrm{H}_{0}$ diterima dan $\mathrm{H}_{1}$ ditolak, artinya pengetahuan perpajakan secara parsial tidak berpengaruh positif terhadap kepatuhan wajib pajak.

b. Pelayanan fiskus $\left(X_{2}\right)$ memiliki nilai t hitung lebih besar dari $\mathrm{t}$ tabel yaitu 2,652>1,660, maka $\mathrm{H}_{0}$ ditolak dan $\mathrm{H}_{2}$ 
diterima, artinya pelayanan fiskus secara parsial berpengaruh positif terhadap kepatuhan wajib pajak.

c. Sanksi denda $\left(X_{3}\right)$ memiliki nilai t hitung lebih besar dari $t$ tabel yaitu 2,070 > 1,660, maka $\mathrm{H}_{0}$ ditolak dan $\mathrm{H}_{3}$ diterima, artinya sanksi denda secara parsial berpengaruh positif terhadap kepatuhan wajib pajak.

\section{Pembahasan}

\section{Pengaruh Pengetahuan Perpajakan Terhadap Kepatuhan Wajib Pajak}

Berdasarkan hasil pengujian diketahui bahwa pengetahuan perpajakan tidak berpengaruh signifikan terhadap kepatuhan wajib pajak, sehingga $\mathrm{H}_{0}$ diterima dan $\mathrm{H}_{1}$ ditolak, artinya pengetahuan perpajakan secara parsial tidak berpengaruh terhadap kepatuhan wajib pajak. Hal ini menjelaskan bahwa pengetahuan perpajakan yang dimiliki dari latar belakang pendidikan wajib pajak tidak menjamin bahwa wajib pajak akan lebih patuh dalam melaksanakan kewajiban perpajakannya. Oleh karena itu diharapkan pemerintah atau petugas pajak memberikan kegiatan yang dapat memberikan pengetahuan terkait perpajakan kepada wajib pajak baik melalui sosialisasi atau penyuluhan maupun melalui media agar wajib pajak dapat memahami dengan betul tentang perpajakan yang pada akhirnya akan meningkatkan kepatuhan wajib pajak.

\section{Pengaruh Pelayanan Fiskus Terhadap Kepatuhan Wajib Pajak}

Berdasarkan hasil pengujian diketahui bahwa pelayanan fiskus secara parsial berpengaruh positif terhadap kepatuhan wajib pajak, sehingga $\mathrm{H}_{0}$ ditolak dan $\mathrm{H}_{2}$ diterima, artinya pelayanan fiskus secara parsial berpengaruh positif terhadap kepatuhan wajib pajak. Hal ini menjelaskan bahwa pelayanan fiskus yang baik kepada wajib pajak cenderung dapat meningkatkan kepatuhaan wajib pajak dalam menjalankan kewajiban perpajakannya. Oleh karena itu diharapkan untuk pemerintah atau petugas pajak memiliki sumber daya manusia yang kompeten agar dapat memberikan pelayanan yang baik dan memuaskan kepada wajib pajak, agar nantinya wajib pajak akan patuh dalam melaksanakan kewajiban perpajakannya.

\section{Pengaruh Sanksi Denda Terhadap Kepatuhan Wajib Pajak}

Berdasarkan hasil pengujian diketahui bahwa sanksi denda berpengaruh positif terhadap kepatuhan wajib pajak, sehingga $\mathrm{H}_{0}$ ditolak dan $\mathrm{H}_{3}$ diterima, artinya sanksi denda berpengaruh positif terhadap kepatuhan wajib pajak. Hal tersebut berarti jika sanksi denda yang semakin tinggi, maka akan cenderung memungkinkan wajib pajak akan patuh dalam melaksanakan kewajiban perpajakannya, karena wajib pajak akan berpikir bahwa hal tersebut akan merugikan mereka, sehingga mereka akan lebih memilih lebih patuh dalam melaksanakan kewajiban perpajakannya. Oleh karena itu untuk pemerintah atau petugas pajak dapat memaksimalkan pelaksanaan sanksi denda ini agar wajib pajak dapat patuh dalam menjalankan kewajiban perpajakannya.

\section{Simpulan}

Berdasarkan pemaparan yang telah di uraikan pada pembahasan, maka dapat diambil beberapa kesimpulan yaitu Pengetahuan perpajakan secara parsial tidak berpengaruh terhadap kepatuhan wajib pajak dengan nilai koefisien 0,187 . Dikarenakan pengetahuan perpajakan yang didapatkan dari latar belakang pendidikan wajib pajak itu tidak menjamin bahwa wajib pajak akan patuh dan terdorong untuk melaksanakan kewajiban perpajakan.

Pelayanan fiskus secara parsial berpengaruh positif terhadap kepatuhan wajib pajak dengan nilai koefisien 0,009 . Dikarenakan bahwa pelayanan fiskus yang baik dan dapat memuaskan wajib pajak, cenderung dapat menambah kepatuhan wajib pajak dalam melaksanakan kewajiban perpajakannya.

Sanksi denda secara parsial berpengaruh positif terhadap kepatuhan wajib pajak dengan nilai koefisien 0,041. Dikarenakan sanksi denda yang diberikan kepada wajib pajak oleh pemerintah, cenderung dapat meningkatkan kepatuhan wajib pajak dalam melaksanakan kewajiban perpajakannya.

\section{Referensi}

Astuti, T. P. dan Yulianto. 2012. Studi Empiris Kepatuhan Pajak Dalam Pembayaran Pajak Bumi Dan Bangunan Pedesaan Dan Perkotaan Kabupaten Sukoharjo. Seminar Nasional dan The $2^{\text {nd }}$ Call For Syariah Paper. 2012. Syariah Paper Accounting FEB UMS: 482-489.

Budhiartama \& Jati. 2016. "Pengaruh Sikap, Kesadaran Wajib Pajak Dan Pengetahuan Perpajakan Pada Kepatuhan Membayar Pajak Bumi Dan Bangunan". E-Jurnal Akuntansi Universitas Udayana. 15(2) : 15101535 .

Bungin, Burhan. 2005. Metodelogi Penelitian Kuantitatif :Komunikasi, Ekonomi, Dan Kebijakan Publik Serta Ilmu - Ilmu Sosial Lainnya. Jakarta : Kencana.

Ernawati, V. 2013. Pengaruh Tingkat Kepatuhan Wajib Pajak Terhadap Penerimaan Pajak Penghasilan Pada Kantor Pelayanan Pajak Pratama Surabaya Genteng. Skripsi. Surabaya : Fakultas Ekonomi Universitas Pembangunan Nasional Veteran Jawa Timur.

Halimi, A. K. 2013. Pengaruh Kesadaran Wajib Pajak, Pelayanan Petugas Pajak, Dan Sanksi Pajak Terhadap Kepatuhan Wajib Pajak Orang Pribadi Yang Melakukan Pekerjaan Bebas Di Wilayah KPP Pratama Jember. Artikel Ilmiah Mahasiswa.

Hudany, Reida Wulan. 2015. "Pengaruh Ekstensifikasi Pajak, Kepatuhan Wajib Pajak, Pemeriksaan Pajak, Penagihan Pajak Dan Surat Paksa Pajak Terhadap Penerimaan Pajak Penghasilan Orang Pribadi Di KPP Pratama Solok". Jom. FEKON. 2(2) : 1-15.

Mappi Jatim. 2013. Penerimaan PBB 2013 Kota Pasuruan Tembus 97,2\% dari Target. Diunduh dari (http://www.mappijatim.or.id/ragamberita/penerimaan-pbb-2013-kota-pasuruan-tembus-972-daritarget.html) pada tanggal (18 November 2016).

Maulana, I. 2012. Pengaruh Kesadaran, Pengetahuan Dan Penerapan SELF ASSESMENT SYSTEM Terhadap Kepatuhan Wajib Pajak ( Studi Empiris Terhadap Wajib Pajak Orang Pribadi yang Terdaftar Di KPP Pratama Jember). Skripsi. Jember : Jurusan Akuntansi Fakultas Ekonomi dan Bisnis Universitas Jember.

Narbuko, Kholid. 2009. Metodelogi Penelitian. Jakarta : Bumi Aksara

Sarwono, J. 2011. Mixed Methods ; Cara Menggabung Riset Kuantitatif dan Riset Kualitatif Secara Benar . Jakarta : Elex Media Komputer.

Sudarmanto, R. Gunawan. 2013. Statistik Terapan Berbasis Komputer Dengan Program IBM SPSS Statistik 19. Jakarta : Mitra Wacana Media. 